\title{
First record of the alien polychaete Naineris setosa (Scolecida; Orbiniidae) in Tyrrhenian Sea (Western Mediterranean)
}

\author{
Giulia Atzori ${ }^{1 *}$, Eduardo López ${ }^{2}$, Pierantonio Addis ${ }^{1}$, Andrea Sabatini ${ }^{1}$ and Serenella Cabiddu ${ }^{1}$
}

\begin{abstract}
During a survey in Santa Gilla, a Tyrrhenian lagoon located in southern Sardinia, several specimens of the alien polychaete Naineris setosa were found. 1) A brief description of the specimens is presented; they possess the rounded prostomium and the crenulated capillary chaetae typical of the genus, but they are characterized by the absolute lacking of uncini or subuluncini in thoracic neuropodia, which is unique trait within Naineris; 2) some environmental characteristics of the collection site are measured; 3 ) the description and the distribution of the specimens are also provided.
\end{abstract}

Keywords: Introduced species, Coastal lagoon, Mediterranean Sea, polychaeta, Naineris setosa

\section{Background}

Occurrence of alien species has altered marine ecosystems all over the world. The Mediterranean Sea is one of the marine areas most affected by biological invasions (Zenetos et al. 2010). A recent revision (Coll et al. 2010) considers it as a biodiversity hotspot, harbouring about 17,000 species, of which more than 600 (3.3\%) are alien ones.

Species belonging to the class Polychaeta can be found in every marine benthic environment from littoral to hadal depths. They play a key role in the trophic ecology of these habitats since they are usual prey for fish and other demersal animals. Many polychaete species show a remarkable ecological plasticity and can adapt to new environments, so these species might have the capacity to become invasive when translocate to new geographic areas. Accordingly, polychaetes rank third in the list of animal groups containing more alien species in the Mediterranean, only behind molluscs and crustaceans, and first in the Italian coasts (Zenetos et al. 2012; Occhipinti-Ambrogi et al. 2010).

The members of the family Orbiniidae, apart from a few little sized species living among algae on hard substrata, are polychaetes that inhabit sediments, especially in shallower depths, where they act as non-selective

\footnotetext{
* Correspondence: giulia.atzori@unica.it

${ }^{1}$ Department of Life and Environmental Sciences, University of Cagliari, Via Fiorelli 1, 09126 Cagliari, CA, Italy

Full list of author information is available at the end of the article
}

detritivorous, burrowing organisms (López 2012). In the Mediterranean Sea, the native fauna of Orbiniidae is composed of 13 species (López 2012) and the genus Naineris Blainville, 1828 is represented only by N. laevigata (Gube, 1855). Apart from N. setosa (Verrill, 1900), other orbiniids, namely N. quadraticeps Day, 1965 and Leitoscoloplos kerguelensis (McIntosh, 1885), have been also recorded as alien species in this area but these reports are currently considered questionable (Zenetos et al. 2010).

In particular, $N$. setosa was originally described from Bermuda Islands. It is known as a widely distributed species in tropical and subtropical latitudes in the western Atlantic Ocean, ranging from its type locality in the North to Sao Paulo in the South (Rizzo and Amaral 2001), with records from SW Florida and Gulf of Mexico (Perkins and Savage 1975), eastern Mexico (Rioja 1960; Hernández-Alcántara and Solís-Weiss 1995), and Belize (Solís-Weiss and Fauchald 1989). The species has been cited also several times in the tropical eastern Pacific, where it has been recorded from Acapulco, Mexico (Hartman 1957), and from Costa Rica, as well as from Cocos and Galapagos Islands (Blake and Giangrande 2011). The latter authors supposed that the species occurs naturally in the Pacific coast of the Americas.

The first report of N. setosa out of its native geographic range was from the Adriatic Sea (Blake and Giangrande 
2011). The specimens were collected in 2003 from an aquaculture farm in Brindisi (Adriatic Sea, Italy) and in spite of being extremely abundant they were restricted to that installation due to its isolated water recirculation system. At the point of time of publishing, the whole facility was closed down and the population became extinct (Blake and Giangrande 2011). Between 2012 and 2013, several specimens of $N$. setosa were collected from Boughrara lagoon (Tunisia) (Khedhri et al. 2014). In this locality the species was reported to be less abundant compared to the population found in the farm facility in Brindisi (maximum reported density of 21 individuals $\mathrm{m}^{-2}$ vs. 500 individuals $\mathrm{m}^{-2}$ ), but its presence in two successive years indicated that the population was established, even though numbers were clearly decreasing from the first to the second year (Khedhri et al. 2014).

The aim of this paper is to report the first record of this non-indigenous species in a Thyrrenian lagoon (Santa Gilla - southern cost of Sardinia), and to provide a description of its distribution.

\section{Review}

\section{Study area}

The Santa Gilla lagoon covers an area of about 1300 ha and is located in the southern coast of Sardinia, close to the urban center of Cagliari, where it lies between the historic and industrial ports (Fig. 1). The Santa Gilla area is one of the most important wetlands in Sardinia, and it is classified as Special Protection Area (Directive 79/ 409/CEE), as Wetland of International Importance under the Ramsar Convention (DM 03/09/1980) and as Site of Community Importance (Directive 92/43/CEE).

\section{Sampling sites and techniques}

The specimens were collected from samples taken in order to characterize the macrozoobenthic community of this lagoon along a salinity gradient. Nine stations were investigated during two surveys (S1, S2, S3, B2, B4, E1, E3, H2 and H4). Stations S1, S2 and S3 were sampled in July and October 2010, and in January and April 2011; stations B2, B4, E1, E3, H2 and H4 were sampled in September and December 2013 and in March and June 2014.

Stations S3, B2 and B4 were located near the freshwater, whereas $\mathrm{S} 1, \mathrm{H} 2$ and $\mathrm{H} 4$ were closer to the sea mouth; stations S2, E1 and E3 were selected in an intermediate area in the central part of the lagoon (Fig. 1). Samples were taken seasonally, every three months, at each station. Each sample consisted of three replicates collected by means of a Van Veen grab (total surface per

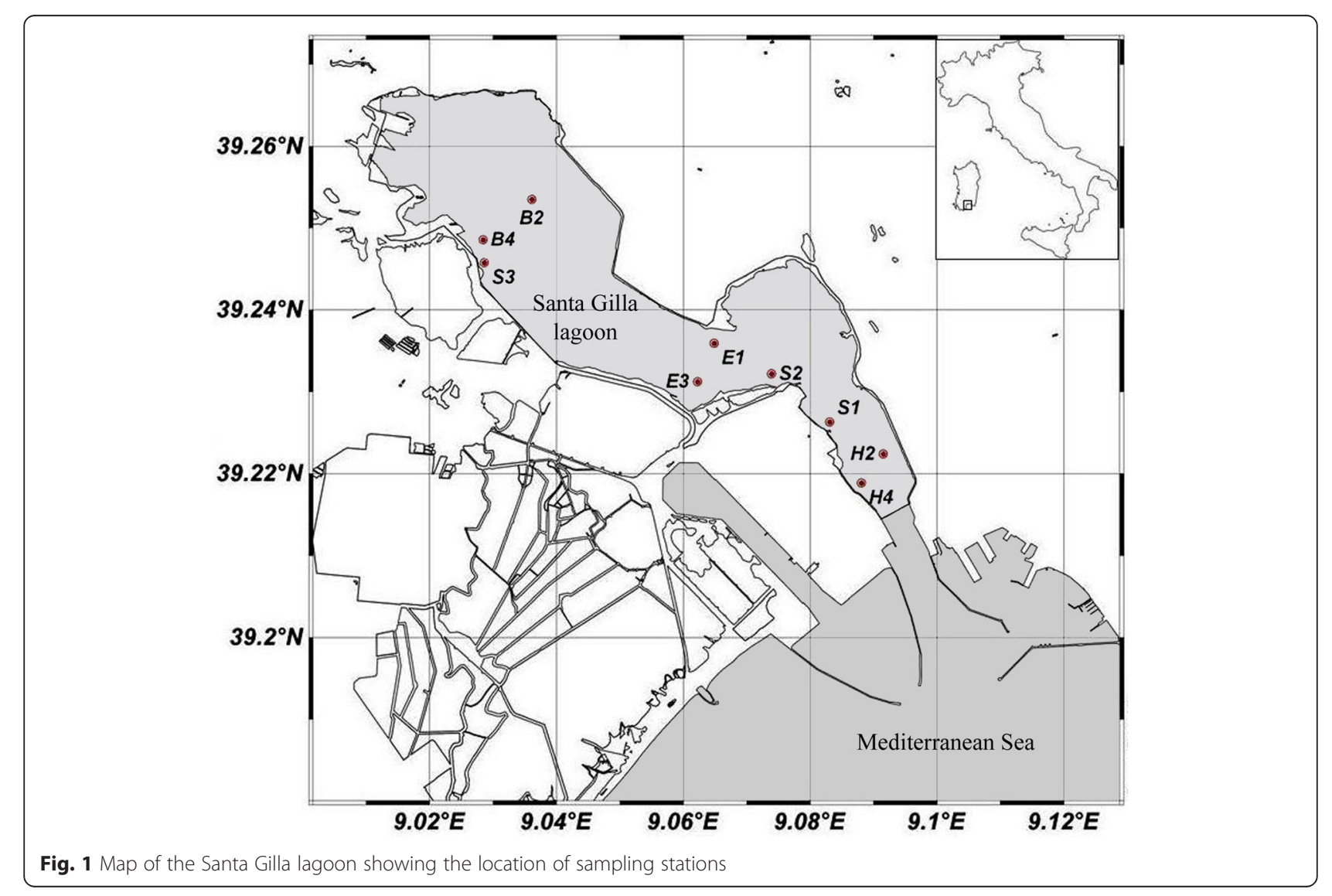


replicate $33 \mathrm{~cm} * 18 \mathrm{~cm})$. Temperature $\left({ }^{\circ} \mathrm{C}\right)$, dissolved oxygen ( $\mathrm{mg} / \mathrm{l}$ and \% sat), $\mathrm{pH}$ and salinity (PSU) were measured in each station with a multiparametric probe (Hanna Instruments HI9828). Each replicate was washed through a $1 \mathrm{~mm}$ mesh screen and the material retained was narcotized with $7.5 \%$ magnesium sulphate solution, fixed in $4 \%$ buffered formalin, dyed with Rose Bengal and preserved in $70^{\circ}$ ethanol. The process of sorting the biological material to taxonomic level of family was accomplished by means of a stereomicroscope under 7-40 $\mathrm{x}$ magnification. Measurements and pictures were made with the same optical equipment adding an ocular micrometer and a camera lucida drawing tube. The various kinds of chaetae were studied with a biological microscope (100-1000 x magnification) provided with an ocular micrometer for measurements and a camera lucida drawing tube for line pictures.

\section{Systematics}

Family ORBINIIDAE

Genus Naineris Blainville, 1828

Naineris setosa (Verrill, 1900)

(Fig. 2)

Aricia setosa Verrill, 1900.

Naineris setosa (Verrill, 1900). (Solís-Weiss and Fauchald 1989; Hartman 1957; Blake and Giangrande 2011; Khedhri et al. 2014; Treadwell 1936).

\section{Material examined}

Station S1: $19^{\text {th }}$ October 2010,13 specimens; $18^{\text {th }}$ January 2011, four specimens. Station S2: $19^{\text {th }}$ October 2010, one specimen; $18^{\text {th }}$ January 2011 , one specimen. Station S3: $19^{\text {th }}$ October 2010 , one specimen. Station E1: $7^{\text {th }}$ March 2014, one specimen; $18^{\text {th }}$ June 2014, one specimen. Station E3: $4^{\text {th }}$ December 2013, one specimen. Station H2: $26^{\text {th }}$ September 2013, 12 specimens; $4^{\text {th }}$ December 2013, 15 specimens; $7^{\text {th }}$ March 2014, 17 specimens; $18^{\text {th }}$ June 2014, one specimen. Station H4: $4^{\text {th }}$ December 2013, one specimen.

\section{Description}

All specimens incomplete; largest specimen $20 \mathrm{~mm}$ long for 52 chaetigers; $5.4 \mathrm{~mm}$ long to chaetiger $10 ; 6.7 \mathrm{~mm}$ wide at middle thorax, $4 \mathrm{~mm}$ wide at first abdominal chaetiger. Body white in alcohol with no colour markings; minute dorsal crest between each pair of branchiae. Prostomium (Fig. 2a) broadly rounded, with two groups of loosely arranged eyespots, without appreciable nuchal organs. Thorax (Fig. 2a) consisting of the peristomium and 19-21 chaetigers; dorso-ventrally flattened, distinctly expanded. All thoracic parapodia biramous; first one similar to the remaining but smaller. Thoracic notopodia (Fig. 2b) bearing a cirriform postchaetal lobe supported by a straight acicula and with a semi-circular projection near

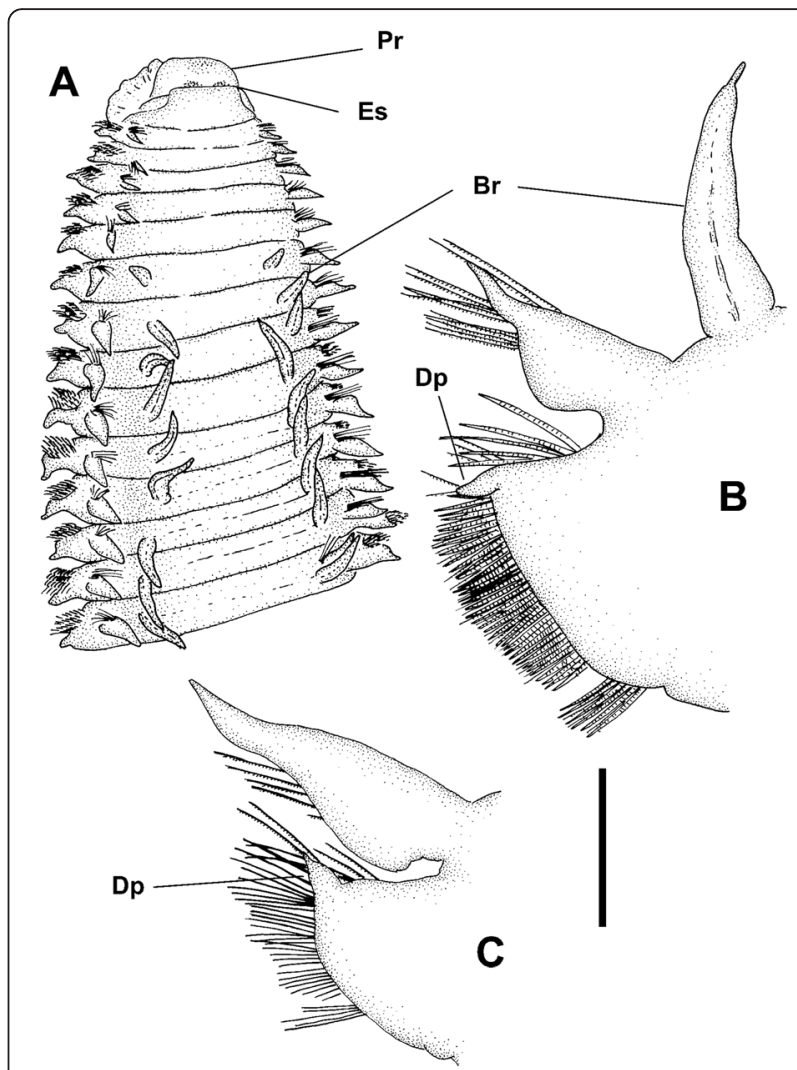

Fig. 2 Description of Naineris setosa (Verrill, 1900): (a) anterior end, dorsal view; (b) left parapodium of chaetiger 14, posterior view; (c) left parapodium of chaetiger 22 (transitional), posterior view. Abbreviations.- Bra: branchia; Dp: dorsal process of neuropodial lobe; Es: eyespots; Pr: prostomium. Scale bar: A, 2.14 mm; B, C, 0.25 mm

the base; with about 25 crenulated capillary chaetae; forked chaetae absent. Thoracic neuropodia (Fig. 2b) as simple ridges, with a high, triangular postchaetal lobe bearing a distinct dorsal process from chaetiger 1; with about 200-250 crenulated capillary chaetae, similar to notochaetae but thicker and slightly curved; arranged in two bundles, those in ventral one less numerous and slightly longer and darker than dorsal ones; uncini and subuluncini absent. Transition to abdomen gradual, with 3-4 transitional chaetigers; transitional notopodia (Fig. 2c) very similar to thoracic ones, with about 25 crenulated capillary chaetae and similar postchaetal lobe; postchaetal lobe of transitional neuropodia shorter than those of thoracic chaetigers but higher and possessing a longer dorsal process, bearing about 80 crenulated capillary chaetae. Abdomen very fragile and easily damaged, incomplete or even completely lacking in all specimens. Notopodia with long, cirriform postchaetal lobe; bearing about 18 crenulated capillary chaetae and 1-2 furcate chaetae, distal tines unequally long, inner spines long shaft with rows of minute spines on the side of the shorter tine. Abdominal parapodia without interramal cirri. Neuropodia broadly 
triangular, supported by a not protruding, almost straight, distally rounded acicula; about 15 crenulated capillary chaetae in two fascicles, dorsal one composed of 3-5 chaetae similar in thickness to corresponding notochaetae, ventral one composed of 10-12 slightly thinner chaetae. Branchiae (Fig. 2a, b) from chaetiger 6; bearing no fimbriation, compressed and tapering to a slender tip; first thoracic pair smaller, progressively increasing in length reaching complete size in chaetiger 8-9; abdominal branchiae longer, with proportionately longer tips. Dorsal retractile statocysts from chaetiger 12 .

\section{Ecology and distribution within the lagoon}

The environmental parameters, as well as coordinates and sampling dates, for the stations in Santa Gilla lagoon where $N$. setosa was found are given in Table 1. Individuals were found scattered all over the basin, being absent only in stations B2 and B4; however, in most cases, the species was represented by a single specimen, occurring only once (stations S3, E3 and H4) or twice (stations S2 and E1), pointing out to occasional and scarce presence of the species at those locations. The remaining two stations harboured greater populations. In station S1, 13 specimens were collected in October 2010, although only 4 were collected in January 2011. Similarly in H2, more than 10 specimens were collected several times (in September and December 2013 and in March 2014); however, population in this station apparently collapsed, and just one specimen was found in June 2014. The higher abundances in these two stations located closer to the open sea indicate a preference for more marine-influenced environmental conditions, contrasting the fact that $N$. setosa seems to be a very euryhaline species that achieved relatively high population densities when salinity dropped to a mere 3.8 in Station H2 during March 2014.

\section{Discussion}

Specimens of N. setosa were collected in Santa Gilla lagoon during the sampling campaigns from 2010 to 2014 suggesting a successful establishment of the species. However, its densities showed dramatic fluctuations between successive seasons and years. The population dynamics have been studied only in a few species of Orbiniidae. For instance, a population of $N$. laevigata, studied in a Mediterranean lagoon (Acquatina lagoon), was composed of individuals that lived two or three years and showed notable variations in its densities, usually related to environmental alterations as temperature and salinity fluctuation (Giangrande and Fraschetti 1995). This is unlikely the explanation for the case of Santa Gilla lagoon, where $N$. setosa population appeared to remain stable when the salinity value plunged.

Naineris. setosa is associated with stressed habitat or is a tolerant opportunistic species. In the Mediterranean Sea it has been previously collected from heavily polluted habitats, such as black anoxic muds (Blake and Giangrande 2011) and in these environments it was able to withstand salinities as high as 43.1 PSU (Khedhri et al. 2014). In Santa Gilla lagoon, in the station where highest densities were achieved, both temperature and salinity fluctuated dramatically on a seasonal pattern, with temperatures ranging from $23.9^{\circ} \mathrm{C}$ in September to $11.6{ }^{\circ} \mathrm{C}$ in December and salinity ranging from 37 (PSU) in September to 3.8 (PSU) in March; in none of these extreme environmental conditions population densities were observed to decrease.

\section{Introduction pathway}

The material herein described was collected in a period running from two years before to one year later the first collecting in Tunisia (Khedhri et al. 2014), revealing the

Table 1 Sample stations: date of collection, geographical coordinates, and environmental features

\begin{tabular}{|c|c|c|c|c|c|c|c|c|}
\hline Station & Day & Latitude & Longitude & Depth (cm) & Temperature $\left({ }^{\circ} \mathrm{C}\right)$ & Salinity & $\mathrm{OD}(\mathrm{mg} / \mathrm{L})$ & OD(\% sat) \\
\hline S1 & 19/10/2010 & 39.22626 & 9.08313 & 90 & 18.20 & 33.2 & 7.30 & 95.1 \\
\hline S2 & 19/10/2010 & 39.23216 & 9.07397 & 79 & 16.20 & 28.6 & 7.12 & 86.9 \\
\hline S3 & 19/10/2010 & 39.24574 & 9.02865 & 80 & 17.23 & 24.7 & 4.89 & 57.8 \\
\hline S1 & 18/01/2011 & 39.22626 & 9.08313 & 79 & 12.49 & 25.0 & 4.44 & 47.5 \\
\hline S2 & 18/01/2011 & 39.23216 & 9.07397 & 79 & 11.39 & 21.3 & 4.72 & 47.9 \\
\hline $\mathrm{H} 2$ & 26/09/2013 & 39.22239 & 9.09158 & 150 & 23.86 & 37.5 & 6.14 & 83.1 \\
\hline E3 & $04 / 12 / 2013$ & 39.23122 & 9.06228 & 140 & 10.10 & 4.0 & 9.18 & 83.8 \\
\hline $\mathrm{H} 2$ & $04 / 12 / 2013$ & 39.22239 & 9.09158 & 150 & 11.60 & 8.5 & 9.02 & 87.7 \\
\hline $\mathrm{H} 4$ & $04 / 12 / 2013$ & 39.21886 & 9.08811 & 135 & 12.10 & 8.0 & 8.95 & 87.6 \\
\hline E1 & 07/03/2014 & 39.23592 & 9.06492 & 125 & 11.30 & 2.1 & 10.33 & 95.7 \\
\hline $\mathrm{H} 2$ & 07/03/2014 & 39.22239 & 9.09158 & 135 & 12.40 & 3.8 & 10.47 & 100.0 \\
\hline E1 & $18 / 06 / 2014$ & 39.23592 & 9.06492 & 160 & 23.19 & 32.3 & 6.34 & 80.0 \\
\hline $\mathrm{H} 2$ & 18/06/2014 & 39.22239 & 9.09158 & 160 & 22.79 & 34.9 & 6.66 & 91.0 \\
\hline
\end{tabular}


first finding in a natural environment of the Mediterranean area. Indeed, the first record was reported from an aquaculture facility near Brindisi (Adriatic Sea, Italy) (Blake and Giangrande 2011) but at the time of the publication the farm was closed and the species was no longer collected. However, all these findings indicate the capacity of the species to colonize suitable habitats in the Western Mediterranean, outside its native area. Thus, a potentially invasive character should be monitored in further studies.

The vector of introduction of $N$. setosa to Mediterranean localities is unknown and very hard to explain. It was presumed that it arrived with the fish reared (Blake and Giangrande 2011), because its presence was limited to the aquaculture facility in Brindisi which cultivated the black seabass Centropristis striata (Linnaeus, 1758), a West Atlantic species (Robins and Ray 1986). It was pointed to package containing seagrass fragments that harboured adult polychaete specimens or to presence of lecitotrophic larvae in the seawater used for live fish transport. In this respect, it must be taken into account that in many European countries effective regulation on live fish imports were implemented some years after the first collection (Katsanevakis et al. 2013). Even though were collected some specimens from a fish farm, it was dismissed that explanation based on the fish species cultured in the lagoon (Khedhri et al. 2014), which never came from the western Atlantic Ocean. This is also the situation of Santa Gilla lagoon, where the only aquaculture activities are devoted to rearing the native mollusc species Ruditapes decussatus and Mytilus galloprovincialis, which are absent in the native area of $N$. setosa.

Alternatively, it was hypothesized (Khedhri et al. 2014) that $N$. setosa reached the lagoon of Boughrara carried by ship traffic but did not determine whether it was as fouling of the ship hull or in the ballast water. The ecological requirements of most orbiniids, which need deep sediments to burrow in when adults (López 2012), are not easily fulfilled in the fouling community, but fouling cannot be totally discarded for $N$. setosa as it has been reported to live on mangrove roots covered by a thin layer of sediment (Solís-Weiss and Fauchald 1989).

As an additional cue to the shipping pathway to explain the arriving of $N$. setosa in the lagoon of Bourghrara, it was taken into account the proximity of Gabes international harbour (Khedhri et al. 2014). In this respect, Santa Gilla lagoon is again a very similar environment being a semi-enclosed water-body close to Cagliari international harbour, which supports very heavy maritime traffic. According to the Port Authority statistics, during 2013, a total of 34.800 .643 tons (whereof 14.221.207 tons of crude), 6293 ships, 343418 passengers, arrived to/departed from the Cagliari port. Although commercial navigation is the most important pathway involved in alien species translocation in the Mediterranean (Nunes et al. 2014), recreational boating is also to be considered since the two lagoons are very close to important touristic centres with large marinas, such as Djerba Island in Tunisia and the town of Cagliari in Sardinia.

\section{Conclusions}

This study demonstrates that a few years after N. setosa appeared in its first locality in the Mediterranean Sea (Brindisi, Adriatic Sea), it scattered across the Western Mediterranean basin colonizing favourable habitats, such as Santa Gilla lagoon in Sardinia (first reported occurrence in October of 2010) and the lagoon of Boughrara in Tunisia (first reported occurrence in August of 2012).

There is not clear evidences of how this species entered in the Mediterranean. The fact that the two findings, in Santa Gilla lagoon and in Boughara lagoon are almost coincident in time could be attributable to multiple and independent introduction events.

However, the successful colonization of the basin by $N$. setosa confirms that in Santa Gilla lagoon ecological conditions for alien species establishment exist, as previously demonstrated the presence of other two alien species, the amphipod Caprella scaura Templeton, 1836 (Cabiddu et al. 2013) and the bivalve Arcuatula senhousia (Benson in Cantor, 1842) (Atzori et al. 2013). Therefore, further monitoring and studies are essential to evaluate the real invasive success of these species and to understand the consequences of their introduction on the native communities.

\section{Competing interests}

The authors declare that they have no competing interests.

\section{Authors' contributions}

GA conceived of the study and drafted the manuscript. EL classified the species and draft the figure. PA participated in the design of the study and helped to draft. AS participated in the acquisition of biological data, measured the environmental parameters and helped to draft. SC participated in the study design and coordination and helped to draft the manuscript. All authors read and approved the final manuscript.

\section{Authors' information}

GA is a PhD who works on macrozoobenthos. EL is an Associate Profesor who works with taxonomy, ecology and systematics of marine invertebrates. $\mathrm{PA}, \mathrm{AS}, \mathrm{SC}$ are researchers at university.

\section{Acknowledgements}

First author acknowledges Guillermo San Martín and Juan Moreira for their warm welcome her in the Marine Biology laboratories of the Universidad Autónoma de Madrid, and for helping her by providing advice and useful literature.

\section{Author details}

'Department of Life and Environmental Sciences, University of Cagliari, Via Fiorelli 1, 09126 Cagliari, CA, Italy. ${ }^{2}$ Departamento de Biología, Universidad Autónoma de Madrid, Darwin 2, 28049 Madrid, Spain.

Received: 3 February 2016 Accepted: 23 February 2016

Published online: 05 April 2016 


\section{References}

Atzori G, Palmas F, Vittori S, Cabiddu S. First record and population structure of the invasive species Arcuatula senhousia (Bivalvia: Mytilidae) in the Santa Gilla lagoon (South Sardinia). Biol Mar Med. 2013;20:116-7.

Blake JA, Giangrande A. Naineris setosa (Verrill, 1900) (Polychaeta, Orbiniidae), an American subtropical-tropical polychaete collected from an aquaculture facility in Brindisi (Adriatic Sea, Italy): A possible alien species. Ital J Zool. 2011;78:20-6.

Cabiddu S, Atzori G, Gallo M, Cau A, Gravina MF. Occurrence of the alien species Caprella scaura (Amphipoda, Caprellidae) in three Tyrrhenian lagoons. Transit Water Bull. 2013;7:62-71.

Coll M, Piroddi C, Steenbeek J, Kaschner K, Ben Rais Lasram F, Aguzzi J et al. The Biodiversity of the Mediterranean Sea: Estimates, Patterns, and Threats. PLoS ONE. 2010; 5(8); doi:10.1371/journal.pone.0011842.

Giangrande G, Fraschetti S. A population study of Naineris laevigata (Polychaeta, Orbiniidae) in a fluctuating environment (Mediterranean Sea). Sci Mar. 1995;59:39-48

Hartman O. Orbiniidae, Paraonidae and Longosomidae. Allan Hancock Pacific Expeditions. 1957;15:183-393.

Hernández-Alcántara P, Solís-Weiss D. Algunas comunidades macrobénticas asociadas al manglar (Rhizophora mangle) en laguna de Términos, Golfo de México. Rev Biol Trop. 1995:43:117-29.

Katsanevakis S, Zenetos A, Belchior C, Cardoso AC. Invading European Seas: Assessing pathways of introduction of marine aliens. Ocean Coast Manage. 2013;76:64-74.

Khedhri I, Lavesque N, Bonifacio P, Djabou H, Afli H. First record of Naineris setosa (Verrill, 1900) (Annelida: Polychaeta: Orbiniidae) in the Western Mediterranean Sea. Biolnvasions Rec. 2014;3:83-8.

López E. Familia Orbiniidae Hartman, 1942. In: Ramos MA et al., editors. Fauna Ibérica. Vol. 36. Annelida Polychaeta III. Madrid: Museo Nacional de Ciencias Naturales; 2012. p. 96-160.

Nunes AL, Katsanevakis S, Zenetos A, Cardoso AC. Gateways to alien invasions in the European Seas. Aquat Invasions. 2014;9:133-44.

Occhipinti-Ambrogi A, Marchini A, Cantone G, Castelli A, Chimenz C, Cormaci M, et al. Alien species along Italian coasts: An overview. Biol Invasions. 2010;13:239-53.

Perkins TH, Savage T. A bibliography and checklist of polychaetous annelids of Florida, the Gulf of Mexico, and the Caribbean region. Fla Mar Res Publ. $1975 ; 14: 1-62$

Rioja E. Estudios anelidológicos. XXIV. Adiciones a la fauna de Anélidos Poliquetos de las costas orientales de México. An Inst Biol México. 1960;14:1-62.

Rizzo AE, Amaral CZ. Spatial distribution of annelids in the intertidal zone in São Sebastião Channek, Brazil. Sci Mar. 2001;65:323-31.

Robins CR, Ray GC. A field guide to Atlantic coast fishes of North America. Boston: Houghton Mifflin Company; 1986.

Solís-Weiss V, Fauchald K. Orbiniidae (Annelida: Polychaeta) from mangrove root-mats in Belize, with a revision of protoariciin genera. Proc Biol Soc Wash. 1989;102:772-92

Treadwell AL. Polychaetous annelids from the vicinity of Nonsuch Island, Bermuda. Zoologica. 1936:21:49-68.

Zenetos A, Gofas S, Verlaque M, Çinar ME, García Raso JE, Bianchi CN, et al. Alien species in the Mediterranean Sea by 2010. A contribution to the application of European Union's Marine Strategy Framework Directive (MSFD). Part I. Spatial distribution. Medit Mar Sci. 2010;11:381-493.

Zenetos A, Gofas S, Morri C, Rosso A, Violanti D, García Raso JE, et al. Alien species in the Mediterranean Sea by 2012. A contribution to the application of European Union's Marine Strategy Framework Directive (MSFD). Part 2. Introduction trends and pathways. Medit Mar Sci. 2012;13:328-52.

\section{Submit your next manuscript to BioMed Central and we will help you at every step:}

- We accept pre-submission inquiries

- Our selector tool helps you to find the most relevant journal

- We provide round the clock customer support

- Convenient online submission

- Thorough peer review

- Inclusion in PubMed and all major indexing services

- Maximum visibility for your research

Submit your manuscript at www.biomedcentral.com/submit
Biomed Central 